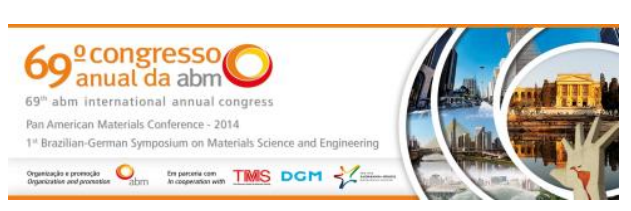

Theme: Physical metallurgy and material behavior at high temperatures

\title{
MICROSTRUCTURAL CHARACTERISTICS AND HIGH TEMPERATURE OXIDATION-CORROSION BEHAVIOR OF FERRITIC STAINLESS STEELS FOR SOLID OXIDE FUEL CELL INTERCONNECTS*
}

\author{
Ananda Moreira Vaz Ourique de Avila ${ }^{1}$ \\ Rodrigo Dias ${ }^{2}$ \\ Roberta Martins de Santana ${ }^{3}$ \\ Luiz Carlos Pereira ${ }^{4}$ \\ José Geraldo de Melo Furtado 5
}

\begin{abstract}
Ferritic stainless steels have been used in the making of high and intermediate temperature operation solid oxide fuel cells (SOFC) interconnects, replacing the ceramic materials. However, at high temperatures, on the order of $700-850{ }^{\circ} \mathrm{C}$, these steels can present significant oxidation and degradation processes, promoting increased electrical resistivity and corrosion losses that result in contamination of the electrodes and reducing the performance and the useful life of the SOFC. Thus, the knowledge on kinetics of oxidation/corrosion of these steels and their relationship with the microstructural transformations are of great importance. In this study, samples of ferritic stainless steels AISI 430, AISI 441 and Crofer22APU ${ }^{\circledR}$ were tested for oxidation at high temperature $\left(800^{\circ} \mathrm{C}\right)$ for long periods of time (up to 3,600 hours) and mass gains were monitored allowing the determination of the oxidation behaviors of these steels. Additionally, the microstructural characteristics of the samples before aging (corrosion-oxidation test) and after various oxidation times were evaluated by optical (OM) and scanning electron microscopy (SEM), as well as by micro chemical elemental analysis (EDS) and X-ray diffraction (XRD) phase analysis. Electrical characterization allowed determination of electrical area-specific resistances (ASR) characteristics of the systems studied, thus relating the electrical and oxidative behaviors of steels evaluated.
\end{abstract}

Keywords: Ferritic stainless steels; Metallic interconnects; Oxidation corrosion; Oxidation kinetics.

1 B.Sc., Fellow Researcher, DTE, Electric Power Research Center (CEPEL), Rio de Janeiro, RJ, Brazil.

2 B.Sc., Laboratory Technician, DTE, CEPEL, Rio de Janeiro, RJ, Brazil.

3 B.Sc., Laboratory Technician, DLF, CEPEL, Rio de Janeiro, RJ, Brazil.

D.Sc., Researcher, DTE, CEPEL, Rio de Janeiro, RJ, Brazil.

5 D.Sc., Professor, Federal University of Rio de Janeiro (UFRJ), Rio de Janeiro, RJ, Brazil.

\footnotetext{
* Technical contribution to the $69^{\text {th }} A B M$ International Annual Congress and to the ENEMET, July $21^{\text {st }}-25^{\text {th }}, 2014$, São Paulo, SP, Brazil.
} 
1(b)). In the last years, there is a greater tendency to develop the planar configuration for SOFC systems, and this type of configuration is capable of achieving very high power density $[8,11]$, characterized by a very thin ElectrolyteElectrodes Assembly (EEA) deposited on an interconnect considerably thicker, but that presents a zone for gas feeding (Figure 1(c)) [6,11]. Another interconnector closes the device and this set constitutes the repeating unit which is forming the stack. Figure 1(d) shown examples of SOFC interconnects.

Under the SOFC operating environments, interconnect must exhibit excellent electrical conductivity (to minimize ohmic losses) with preferably nearly $100 \%$ electronic conduction, since interconnect provides the conductive path for electrical current to pass between the electrodes and to the external circuit. A value of $1 \mathrm{~S} / \mathrm{cm}$ is a well-accepted minimum electrical conductivity for the usefulness of interconnects in SOFC [6,7].

Interconnect should have adequate stability in terms of dimension, microstructure, chemistry, and phase at operating temperature around $700-850^{\circ} \mathrm{C}$ in both reducing and oxidizing atmospheres, since they are exposed to oxygen on one side and fuel on the other. Interconnect should display exceptionally low permeability for oxygen and hydrogen to minimize the crossover direct combination of oxidant and fuel during cell operation. Thermal expansion coefficient (TEC) of interconnect should be comparable to those of electrodes and electrolyte between ambient and operating temperatures, so that the thermal stress developed during stack startup and shutdown could be minimized. No reaction or inter diffusion between interconnect and its adjacent components, specifically, anode and cathode, is allowed to occur under operation conditions. Interconnect should possess fairly good thermal conductivity (5 W/m.K is considered to be the low limit) $[5,7]$.

Excellent oxidation, sulfidation and carburization resistances are required attributes for interconnect to qualify for application in SOFC-like environments. In addition, cost-effective manufacture of fuels cells requires that the interconnect materials be easy to fabricate. The costs of raw materials as well as manufacture processes for interconnect are also supposed to be as low as possible so that they will not present hurdles to commercialization. Finally, interconnect should also show adequate high temperature strength and creep resistance. This requirement is of special relevance to the planar SOFC where interconnect serves as a structural support.

With the possibility of reducing the operating temperature of $900^{\circ} \mathrm{C}-1,000^{\circ} \mathrm{C}(\mathrm{HT}$ SOFC, high temperature SOFC) to $650^{\circ} \mathrm{C}-800^{\circ} \mathrm{C}$ (IT-SOFC, intermediate temperature SOFC) due to development of new materials and constructive refinements of the device that allowed the employment electrolyte reduced thicknesses, which do not require temperatures as high as those of the firstgeneration of SOFC, it became possible to use metal interconnects to replace the purely bulk ceramic interconnects based on lanthanum chromites, the which can represent significant gains in manufacturing (via simplification of procedures) and operating performance of SOFC [7-9].

Thus, in recent years, ferritic stainless steels (FSS) have been intensively considered for this application [8-13]. However, about $800^{\circ} \mathrm{C}$, FSS have problems caused by volatilization of $\mathrm{Cr}$ contained therein and the overgrowth of chromium oxide $\left(\mathrm{Cr}_{2} \mathrm{O}_{3}\right)$ layer, with high electrical resistivity, which tends to increase the electrical contact resistance (ECR) between the interconnector and the SOFC electrodes, causing loss of performance and promoting the degradation of the device. Then, the knowledge on kinetics of oxidation/corrosion of these steels and their relationship with the microstructural transformations are of great importance.

\footnotetext{
* Technical contribution to the $69^{\text {th }}$ ABM International Annual Congress and to the ENEMET, July $21^{\text {st }}-25^{\text {th }}$, 2014, São Paulo, SP, Brazil.
} 


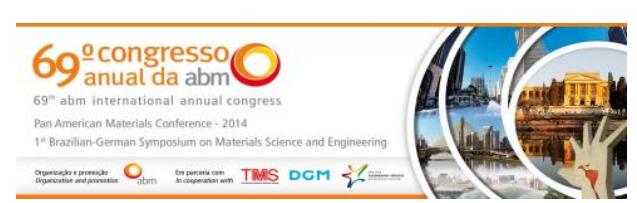

In this context, in the present study, samples of ferritic stainless steels AISI 430, AISI 441 and Crofer22APU ${ }^{\circledR}$ were tested for oxidation at high temperature $\left(800^{\circ} \mathrm{C}\right)$ for long periods of time (up to 3,600 hours) and mass gains were monitored allowing the determination of the oxidation behaviors of these steels. Additionally, the microstructural characteristics of the samples before aging (corrosion-oxidation test) and after various oxidation times were evaluated by optical (OM) and scanning electron microscopy (SEM), as well as by micro chemical elemental analysis (EDS) and X-ray diffraction (XRD) phase analysis. Electrical characterization allowed determination of electrical area-specific resistances (ASR) characteristics of the systems studied, thus relating the electrical and oxidative behaviors of steels evaluated.

\section{MATERIAL AND METHODS}

In this work, studies were performed with the ferritic stainless steels (FSS) AISI 430, AISI 441 and Crofer $^{\circledR 22 A P U, ~ w h i c h ~ h a s ~ t h e ~ r i g h t ~ c h a r a c t e r i s t i c s ~ f o r ~ i n t e r c o n n e c t s ~ i n ~}$ high temperature fuel cells. Each FSS has different chemical elemental composition as shown in Table 1.

Table 1. Chemical composition (wt\%) of the ferritic stainless steels evaluated (except Fe).

\begin{tabular}{c|ccccccc}
\hline Ferritic stainless steels & C & Mn & P & S & Si & Cr & Ni \\
\hline AISI 430 & 0.12 & 1.0 & 0.04 & 0.03 & 1.0 & $16.0-18.0$ & 0.75 \\
\hline AISI 441 (a) & 0.03 & 1.0 & 0.04 & 0.03 & 1.0 & $17.5-19.5$ & 1.0 \\
\hline Crofer22APU ${ }^{\circledR}$ (b) & 0.03 & $0.3-0.8$ & 0.05 & 0.02 & 0.5 & $20.0-24.0$ & \\
\hline
\end{tabular}

Others: (a): $\mathrm{Ti}=0.1-0.5,9 \times \mathrm{C}+0.3 \leq \mathrm{Nb} \leq 0.9$; (b): $\mathrm{Cu} \leq 0.5,0.03 \leq \mathrm{Ti} \leq 0.2, \mathrm{Al} \leq 0.5,0.04 \leq \mathrm{La} \leq 0.2$.

For the oxidation test, twelve samples of each material (FSS) were placed in an alumina sample holder. The oxidation test was done in a laboratory furnace and at $800^{\circ} \mathrm{C}$ during 3,600 hours. Every 100 hours, the sample holder was removed and cooled in air for approximately one hour. After this time the samples were weighed on an analytical four decimal place balance. From this test was possible to evaluate the high temperature oxidation kinetics of these steels. As during the first weighing was observed that the AISI 430 and AISI 441 steels left a fine powder on the sample holder, a different watch-glass was used during weighing for each steel and between each sample weighing the balance was tared again.

After 3,600 hours of oxidation, samples were selected for microstructural characterization both as the chemical composition with optical microscope (OM), scanning electron microscope (SEM, Jeol JSM-64602 LV)), energy dispersive X-ray spectroscopy (EDS, Link ISIS, Oxford Instruments) and X-ray diffraction (XRD). For the analyzes by OM, SEM and EDS, the chosen samples were cut in half to prevent the edges influence the result. A cold cut with gold wire was done, then the samples were prepared metallographically and analyzed.

The samples were obtained from the cut of a plate with $1 \mathrm{~mm}$ thickness for each steel. The samples have dimensions of $15 \mathrm{~mm}$ (length) $\times 10 \mathrm{~mm}$ (width) $\times 1 \mathrm{~mm}$ (thickness). After cutting, the samples were cleaned and had all surfaces grinded with metallographic \# 600 and \# 1200 sandpaper.

* Technical contribution to the $69^{\text {th }} A B M$ International Annual Congress and to the ENEMET, July $21^{\text {st }}-25^{\text {th }}$, 2014, São Paulo, SP, Brazil. 


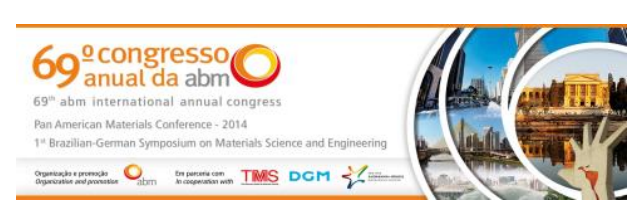

In order to do the microstructural characterization of the as received and aged steels, a sample of each steel was hot embossed with Bakelite. After hardening Bakelite, the usual grinding method was performed with sandpaper water. The order of sandpaper use was: \# 220, \# 320, \# 400 and \# 600. The polishing was done in two steps: the first one with different diamond particle suspensions $(9,3$ and $1 \mu \mathrm{m})$ and the second one with a suspension of colloidal silica particles, thus ensuring a smooth surface free of scratches.

The electrothermal characterization, ASR measurement, based on the four-probe method allowed determination of the specific electric resistance per unit area (ASR) according to procedures and devices considered in literature [8-10].

\section{RESULTS AND DISCUSSION}

From the data obtained during the oxidation test of the ferritic stainless steels AISI 430, AISI 441 and Crofer $^{\circledR} 22$ APU, it was possible to plot a graph of specific mass gain over the area $(\Delta \mathrm{m} / \mathrm{A})$ versus time of the test. Observing Figure 1 we can confirm that the oxidation kinetics are approximately parabolic.
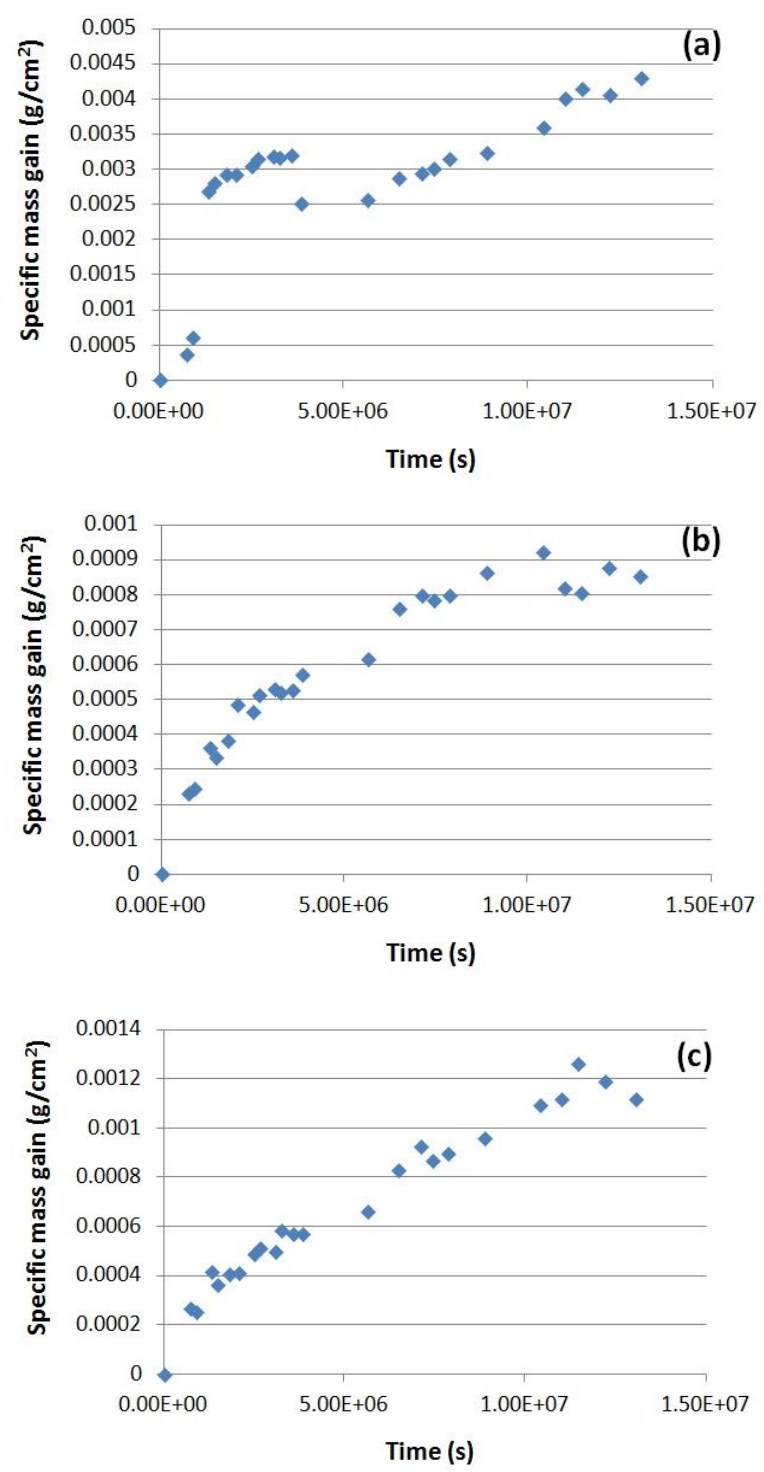

Figure 2. Oxidation behavior results of (a) AISI430, (b) AISI441 and (c) Crofer ${ }^{\circledR} 22 \mathrm{APU}$ at $800^{\circ} \mathrm{C}$.

\footnotetext{
* Technical contribution to the $69^{\text {th }}$ ABM International Annual Congress and to the ENEMET, July $21^{\text {st }}-25^{\text {th }}, 2014$, São Paulo, SP, Brazil.
} 
From the results shown in Figure 2 above, it is possible to obtain the parabolic oxidation constant (kp) each rated steel as shown in Table 2.

Table 2. Parabolic oxidation constant $(\mathrm{kp})$ of oxidation of ferritic stainless steels AISI 430 , AISI 441 and Crofer $^{\circledR} 22 \mathrm{APU}$.

\begin{tabular}{c|c|c}
\hline Ferritic Stainless Steel & $\mathrm{k}_{\mathrm{p}}\left(\mathrm{g}^{2} \cdot \mathrm{cm}^{-4} \cdot \mathrm{s}^{-1}\right)$ & Mean dispersal (\%) \\
\hline AISI 430 & $2.24 \times 10^{-12}$ & 38.5 \\
\hline AISI 441 & $4.15 \times 10^{-14}$ & 6.3 \\
\hline Crofer ${ }^{\circledR 2} 2 \mathrm{APU}$ & $6.12 \times 10^{-14}$ & 4.8 \\
\hline
\end{tabular}

Although AISI 441 has the lowest parabolic oxidation constant, the results dispersion was greater than the results of Crofer $^{\circledR} 22 \mathrm{APU}$ (Figure 2). So analyzing only the $\mathrm{kp}$ value, it is only possible to conclude that the AISI 430 has the worst air oxidation behavior at high temperatures $\left(800^{\circ} \mathrm{C}\right)$.

Optical microscopy of AISI 430 steel is observed in Figure 3. It is possible to observe the coalescence and growth of dark spots after aging, highlighting areas of corrosion. This is due to the diffusion of some species in these regions [8].


Figure 3. Optical microscopy of AISI430 (a) before and (b) after aging.

Optical microscopy of AISI 441 steel is observed in Figure 4. It is observed that after aging was verified substantial erosion at grain boundaries and thus they appear more marked and eroded. This discontinuity at the grain boundaries may represent a possible sensitization, which may be indicative of intergranular corrosion. From dark spots observed in the micrograph of steel as received increased significantly quantity with the AISI 441 aging.

Complementing, optical microscopy of Crofer $^{\circledR} 22 \mathrm{APU}$ steel is observed in Figure 5. The microstructure aspect remained similar between the samples as received and aged. The grain boundaries remained thin, continuous and homogeneous. The size of the darkest points has not changed much. All these analyzes allow us to conclude that steel $\operatorname{Crofer}^{\circledR} 22 \mathrm{APU}$ showed good microstructural stability when subjected to high temperatures during the time tested.

SEM-EDS results of AISI 430 before aging microscopy are in Figure 6(left). From the comparison between the dark point (point 1) and the matrix (point 2), it is possible to conclude that the dark spots have higher chromium content. On the other hand, from the EDS results of the aged AISI 430, Figure 6(right), it is observed that the layer

\footnotetext{
* Technical contribution to the 69th ABM International Annual Congress and to the ENEMET, July $21^{\text {st }}-25^{\text {th }}$, 2014, São Paulo, SP, Brazil.
} 


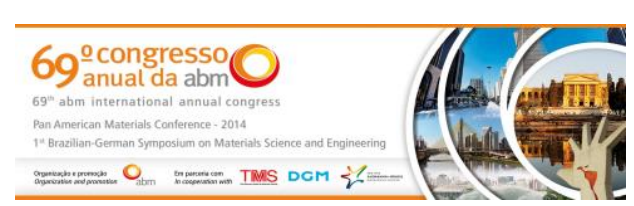

formed on the metal is composed by chromium oxide and the interface is rich in silicon, indicating the formation of silicon oxide during aging.

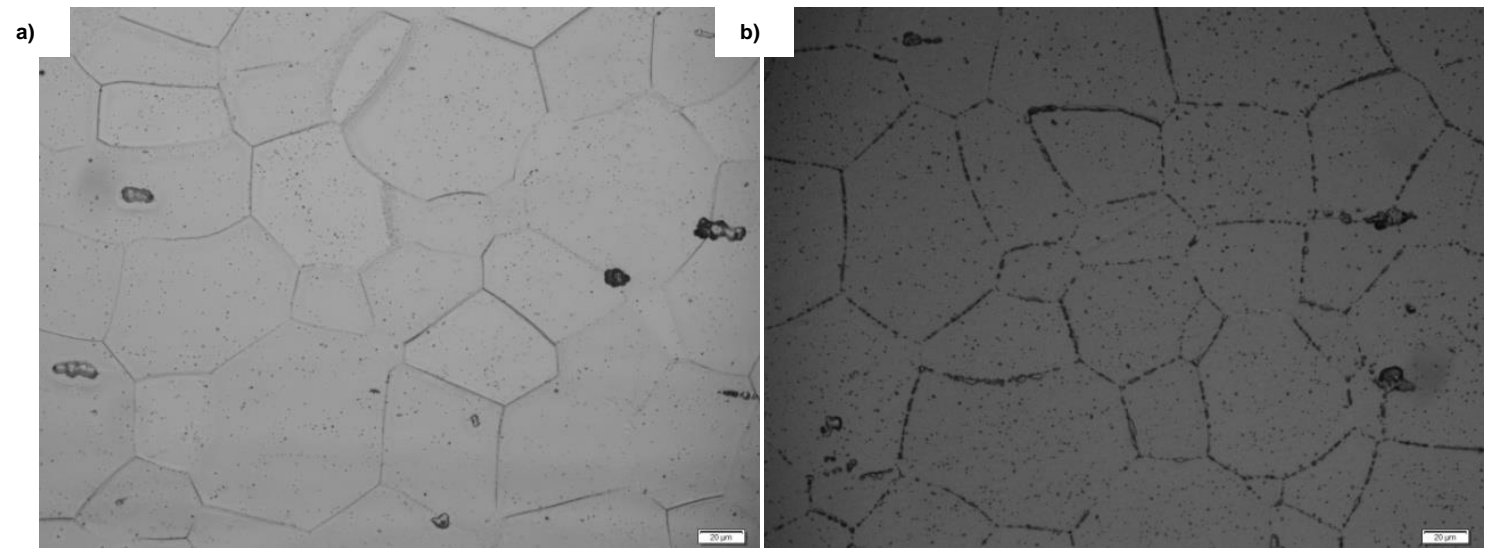

Figure 4. Optical microscopy of AISI441 (a) before and (b) after aging.
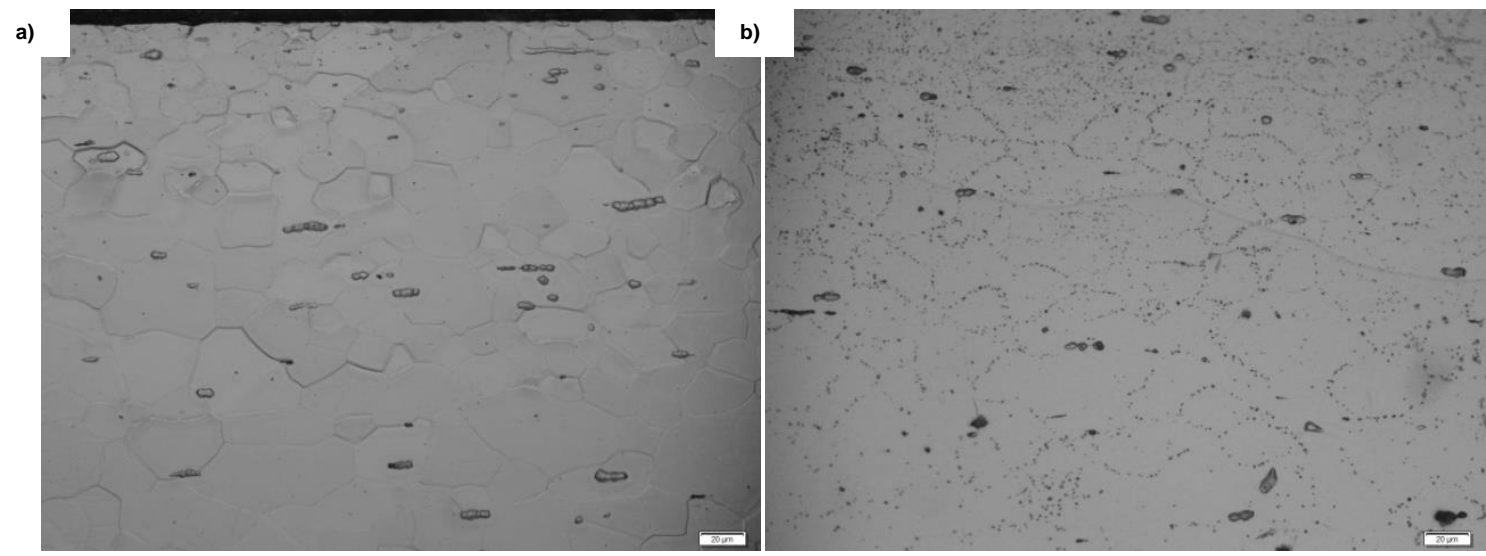

Figure 5. Optical microscopy of Crofer®22APU (a) before and (b) after aging.
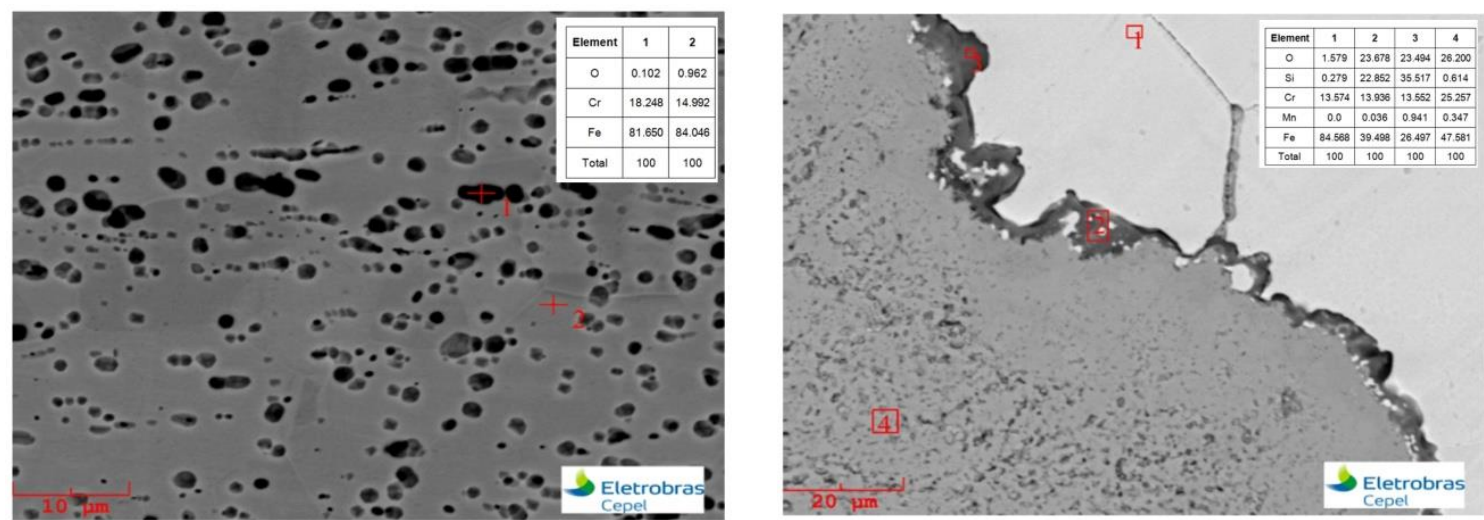

Figure 6. SEM-EDS analysis of AISI 430 before aging (left) and after aging (right).

EDS results of AISI 441 before aging, Figure 7(left), shows that the difference between the grains is only the color, not compositional.

EDS results of AISI 441 aged, Figure 7(right), are not very conclusive, but it is possible to analyze that the niobium concentration is high, showing a likely diffusion of this element to the grain boundaries.

* Technical contribution to the $69^{\text {th }}$ ABM International Annual Congress and to the ENEMET, July $21^{\text {st }}-25^{\text {th }}$, 2014, São Paulo, SP, Brazil. 


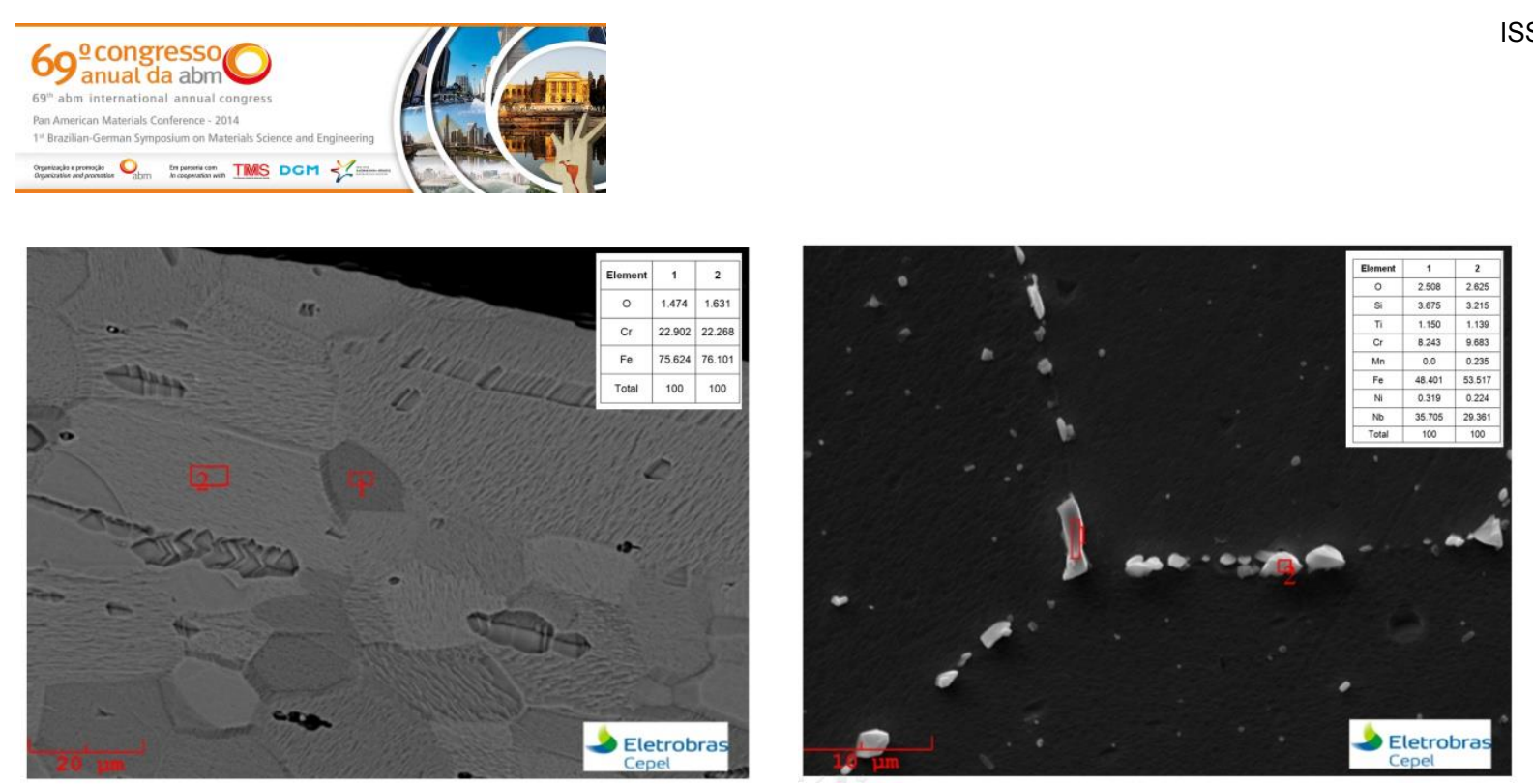

Figure 7. SEM-EDS analysis of AISI 441 before aging (left) and after aging (right).

All points of Crofer $^{\circledR} 22 A P U$ microscopy analyzed by EDS (Figure $8($ left)) have similar values for the elemental composition, and so it is not possible to draw further conclusions. Analyzing the EDS results of $\operatorname{Crofer}^{\circledR} 22 \mathrm{APU}$ after aging, Figure 8(right), is possible to observe that there was the formation of a chromium oxide layer on the metals surface but much smaller than that of the AISI 430.
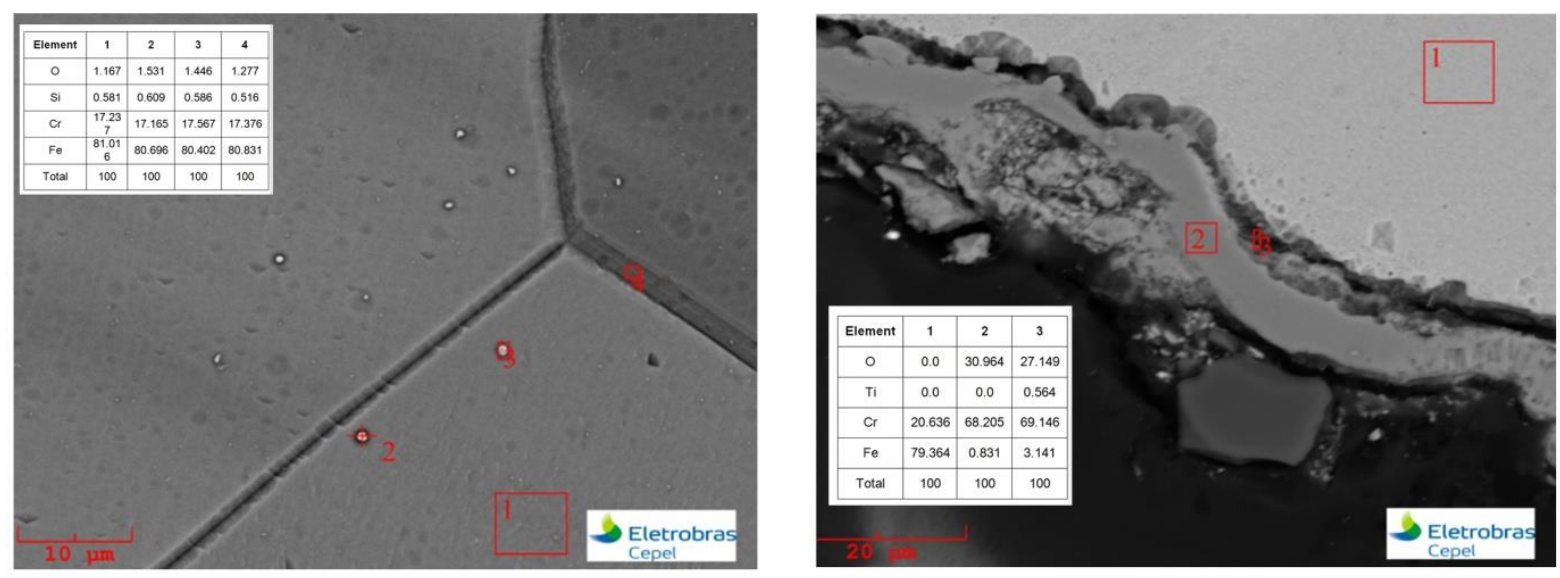

Figure 8. SEM-EDS analysis of Crofer ${ }^{\circledR 22 A P U}$ before aging (left) and after aging (right).

In Figures 9, 10 and 11 the X-ray diffractograms of the surfaces of the FSS samples as received and after aging results are shown.
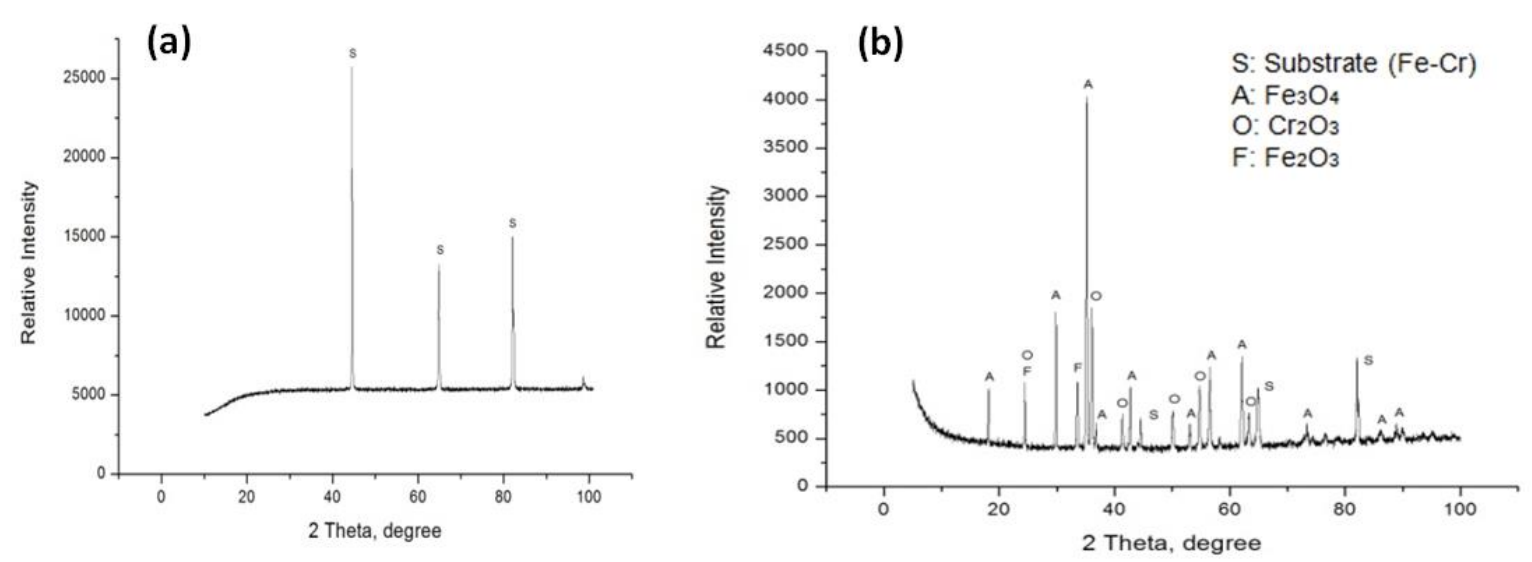

Figure 9. XRD results of AISI 430 (a) as received and (b) after aging.

\footnotetext{
* Technical contribution to the $69^{\text {th }} A B M$ International Annual Congress and to the ENEMET, July $21^{\text {st }}-25^{\text {th }}, 2014$, São Paulo, SP, Brazil.
} 

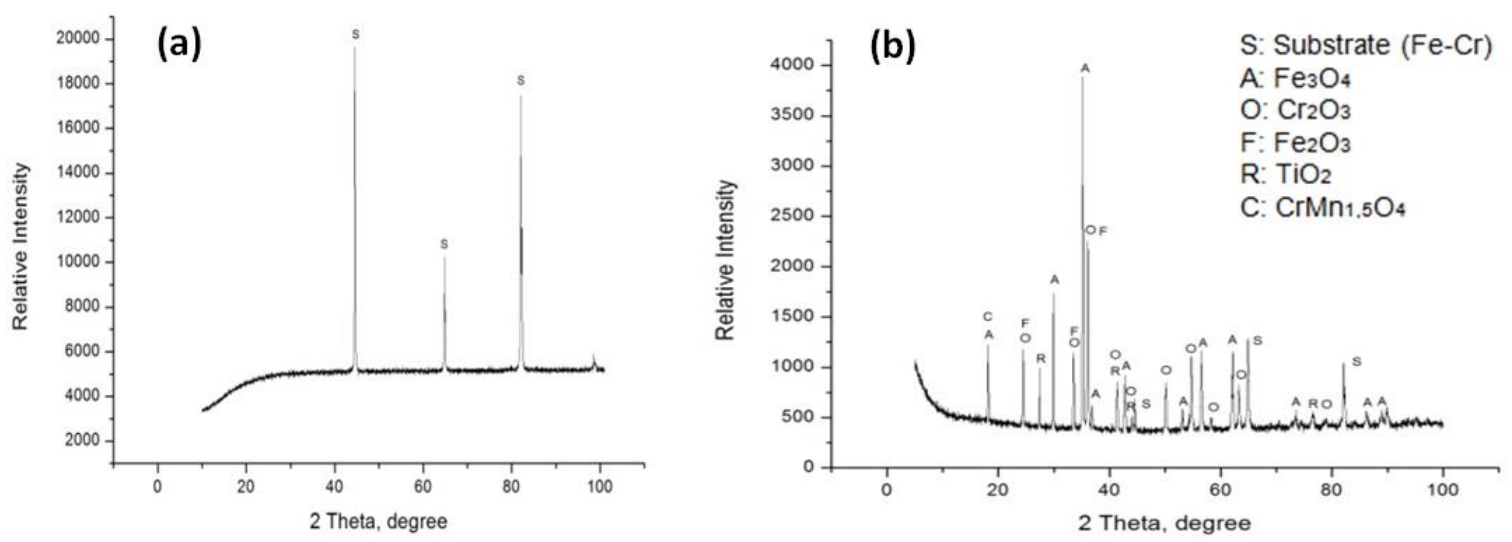

Figure 10. XRD results of AISI 441 (a) as received and (b) after aging.
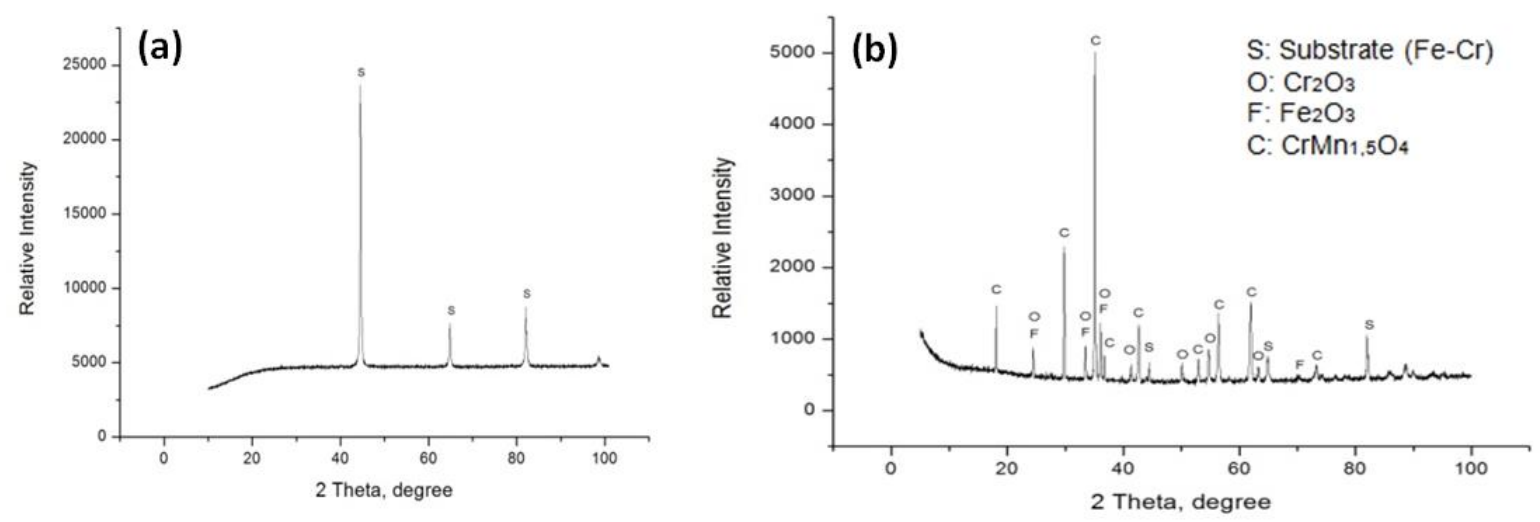

Figure 11. XRD results of Crofer $^{\circledR} 22 A P U(a)$ as received and (b) after aging.

From the XRD results, it was possible to obtain the compounds formed on the surface of different ferritic stainless steels studied.

In the three stainless steels was possible to observe the formation of metal oxides, mainly $\mathrm{Cr}_{2} \mathrm{O}_{3}$ and $\mathrm{Fe}_{2} \mathrm{O}_{3}$, due to high temperature and oxygen exposure [8, 9]. In fact, the excessive growth of the oxide layer, mainly of $\mathrm{Cr}_{2} \mathrm{O}_{3}$, increases the area specific electrical resistances (ASR) of the material and the contact resistance between the interconnector and electrodes in a fuel cell application, causing loss of performance and favoring the devices degradation [8-10]. Thus, the XRD results corroborate with the results and observations of both analyzes by microscopy and gravimetric assessment, since the thickness of the chromium oxide (or even mixed oxide) layer can be determined by direct microscopy or estimated from knowledge of the kinetics of oxidation of the materials in question ( $k_{p}$ values).

Table 3 shows the results obtained from ASR measurements for up to 3,600 hours of exposure to the test samples by oxidation at $800^{\circ} \mathrm{C}$ in air. As would be expected, mainly due to the diffusion of chromium and the subsequent formation of the surface oxide layer - as can be seen in the microscopic and gravimetric analyses previously considered-, an increase of the values of ASR over time oxidation occurs. Confirming the previous results, the FSS AISI 430 was more sensitive to the oxidation process, since the value of ASR reached after $3600 \mathrm{~h}$ was about 4 times higher than the original, while for steels AISI 441 and Crofer $^{\circledR 22 A P U}$ these values were respectively 2.8 and 2.4 times greater.

\footnotetext{
* Technical contribution to the $69^{\text {th }} A B M$ International Annual Congress and to the ENEMET, July $21^{\text {st }}-25^{\text {th }}$, 2014, São Paulo, SP, Brazil.
} 
8 Shaigan N, Qu W, Ivey DG, Chen W. A review of recent progress in coatings, surface modifications and alloy developments for solid oxide fuel cell ferritic stainless steel interconnects. Journal of Power Sources. 2010;195:1529-42.

9 Tondo E, Boniardi M, Cannoletta D. Electrodeposition of yttria/cobalt oxide and yttria/gold coatings onto ferritic stainless steel for SOFC interconnects. Journal of Power Sources. 2010;195:4772-78.

10 Wu J, Liu X. Recent Development of SOFC Metallic Interconnect. Journal of Materials Science \&Technology. 2010;26:293-305.

11 Dheeradhada VS, Cao H, Alinger MJ. Oxidation of ferritic stainless steel interconnects: Thermodynamic and kinetic assessment. Journal of Power Sources. 2011;196:1975-82.

12 Froitzheim J, Meier GH, Niewolak L. Development of high strength ferritic steel for interconnect application in SOFCs. Journal of Power Sources. 2008;178:163-173.

13 Cooper L, Benhaddad S, Wood A, Ivey DG. The effect of surface treatment on the oxidation of ferritic stainless steels used for solid oxide fuel cell interconnects. Journal of Power Sources. 2008;184:220-228.

* Technical contribution to the $69^{\text {th }} A B M$ International Annual Congress and to the ENEMET, July $21^{\text {st }}-25^{\text {th }}, 2014$, São Paulo, SP, Brazil. 